\title{
EXPERIMENTAL SALMONELLOSIS
}

\section{New Toxic Fraction (L) Obtained from SALMonelLa enteritidis aNd Its Immunological Properties}

\author{
MASAYA KAWAKAMI, NOBUTAKA OSAWA, AND SUSUMU MITSUHASHI \\ Department of Microbiology, School of Medicine, Gunma University, Maebashi, Japan
}

Received for publication 2 July 1963

\begin{abstract}
KawaKami, Masaya (Gunma University, Maebashi, Japan), NobUtaka Osawa, AND Susumu Mitsuhashi. Experimental salmonello. sis. III. New toxic fraction (L) obtained from Salmonella enteritidis and it.s immunological properties. J. Bacteriol. 86:872-879. 1963.-A method is described for the purification of the heat-labile toxins of a fully virulent strain, 116-54, of Salmonella enteritidis by ion-exchange chromatography. One component of the heat-labile toxin (L) was homogeneous, as evidenced by the results of the ultracentrifugal analysis and agar gel diffusionitest. The mouse $\mathrm{LD}_{50}$ was $1.3 \mu \mathrm{g}$, and chemical studies indicated that this toxin was a simple protein in nature. It was also evidenced by chemical and immunological tests that this toxin differs from the $\mathrm{O}$ antigen (lipopolysaccharide-protein complex).
\end{abstract}

In a previous paper (Mitsuhashi et al., 1958) it was reported that mice which were superimmunized with live vaccine of Salmonella enteritidis resisted 1000 MLD of the same virulent strain injected intravenously. In contrast, a vaccine of killed $S$. enteritidis increased the survival time of mice after challenge, but it was not effective in preventing ultimate death as a result of infection (Ushiba et al., 1953; Mitsuhashi et al., 1958). During the course of the study on immunogenic substances which confer antibacterial protection against the infection of mice with $S$. enteritidis, toxic substances were obtained from the culture filtrate or bacterial cells of $S$. enteritidis.

This paper presents results of studies on the purification and properties of toxic substances.

\section{Materials and Methods}

Bacterial strain and culture medium. A virulent strain, 116-54, of S. enteritidis was used through- out this study. The strain was lyophilized and stored in a refrigerator at $-5 \mathrm{C}$. About $50 \mathrm{mg}$ of the bacterial cells, which were harvested from an agar medium, were inoculated into a jar containing 10 liters of a semisynthetic culture medium. This medium was composed of $\mathrm{Na}_{2} \mathrm{HPO}_{4} \cdot 12 \mathrm{H}_{2} \mathrm{O}$, $80 \mathrm{~g} ; \mathrm{KH}_{2} \mathrm{PO}_{4}, 20 \mathrm{~g} ;\left(\mathrm{NH}_{4}\right)_{2} \mathrm{SO}_{4}, 10 \mathrm{~g} ; \mathrm{MgSO}_{4}$. $7 \mathrm{H}_{2} \mathrm{O}, 1 \mathrm{~g}$; sodium citrate, $5 \mathrm{~g}$; glucose, $20 \mathrm{~g}$; Casamino Acids (Difco), $20 \mathrm{~g}$; yeast extract (Difco), $20 \mathrm{~g}$; and distilled water, 10 liters.

The medium was adjusted to $\mathrm{pH}$ 7.6. The inoculated medium was incubated at $37 \mathrm{C}$ for 20 $\mathrm{hr}$ with aeration. Air was bubbled through at a flow rate of 8.8 liters per min.

Preparation of crude extract. The bacterial cells were harvested and washed with $0.85 \%$ saline. Wet packed cells $(50 \mathrm{~g})$ were suspended in $200 \mathrm{ml}$ of 0.05 м phosphate buffer ( $\mathrm{pH} 6.8$ ). After heating the bacterial suspension at $56 \mathrm{C}$ for $12 \mathrm{~min}$, it was cooled to $4 \mathrm{C}$, and the $\mathrm{pH}$ was adjusted to 11.0 by the addition of $1 \mathrm{~N} \mathrm{NaOH}$. The suspension was maintained at $4 \mathrm{C}$ for $2 \mathrm{hr}$ with gentle agitation by means of a magnetic stirrer, and then was neutralized with $1 \mathrm{~N}$ acetic acid. The cells were removed by centrifugation.

To the extract, solid ammonium sulfate was added to $70 \%$ saturation, and the precipitated materials were collected by centrifugation. After overnight dialysis of the materials against 0.001 м phosphate buffer ( $\mathrm{pH} 6.0$ ), insoluble materials were removed by centrifugation at 10,000 $\times g$ for $20 \mathrm{~min}$. The crude extract thus prepared was frozen in a Dry Ice-acetone mixture and stored at $-20 \mathrm{C}$.

Preparation of endotoxin. An endotoxin was prepared from $S$. enteritidis $116-54$ by the method of Westphal et al. (1952). The phenol extract of bacterial cells was dialyzed against water, and to it were added 6 volumes of ethanol. The precipitates formed were dissolved in $0.05 \mathrm{~m}$ phosphate buffer $(\mathrm{pH} 6.8)$ to a concentration of $3 \%$. The 
fraction which was precipitated by centrifugation at 76,000 $\times g$ for $60 \mathrm{~min}$, and was not precipitated at $15,000 \times g$ for $10 \mathrm{~min}$, was collected. This fraction was further purified by starch electrophoresis; the material was placed on the midzone of a starch block ( 1.5 by 7 by $40 \mathrm{~cm}$ ) steeped with Veronal buffer ( $\mathrm{pH} 8.6$; ionic strength, 0.05). After being charged for $16 \mathrm{hr}$ at 200 to 300 $\mathrm{v}$ and $16 \mathrm{ma}$, a fraction, which moved to the cathode and was abundant in methylpentose, was extracted. This fraction was dialyzed and lyophilized. The endotoxin thus obtained was electrophoretically and ultracentrifugally homogenous. Endotoxin prepared by the method of Goebel, Binkley, and Perlman (1945) was also used (i.e., by pyridine extraction, acetone fractionation, and further by starch electrophoresis).

The protein component of the endotoxin, which was separated from $400 \mathrm{mg}$ of endotoxin, was dissolved in $20 \mathrm{ml}$ of water, and an equal volume of $0.2 \mathrm{~N}$ acetic acid was added. After hydrolysis in boiling water for $10 \mathrm{~min}$, the resulting precipitates were concentrated by centrifugation at $4 \mathrm{C}$. The precipitates were washed once with 20 $\mathrm{ml}$ of $0.1 \mathrm{~N}$ acetic acid and dissolved in $2 \mathrm{ml}$ of 0.1 m phosphate buffer ( $\mathrm{pH}$ 7.5). The insoluble materials were removed by centrifugation at $10,000 \times g$ for $10 \mathrm{~min}$. The supernatant was purified by two successive precipitations with acetic acid as described above. Finally, the precipitates were dissolved in $0.05 \mathrm{~m}$ phosphate buffer ( $\mathrm{pH}$ 7.5) and dialyzed against the same buffer.

Ultracentrifugal analysis. The ultracentrifugal analysis was performed with a model E Spinco ultracentrifuge.

Serological tests. Antibacterial serum was obtained by immunizing rabbits with $S$. enteritidis 116-54; to an overnight broth culture, 0.04 volume of formalin was added and incubated overnight. Each rabbit received an injection of eight increasing doses ( 0.5 to $3 \mathrm{ml}$ ) of this bacterial suspension every 2 days. On the fifth day after the last immunization, the animal was bled. The titers of $\mathrm{O}$ and $\mathrm{H}$ were $1: 800$ and $1: 12,000$, respectively. Another rabbit was immunized with fraction $\mathrm{C}$ by administration of a daily dose of 10 to $120 \mu \mathrm{g}$ for 18 days; the total dose was 1250 $\mu \mathrm{g}$. A separate rabbit was also immunized daily for 12 days with 20 to $320 \mu \mathrm{g}$ of the protein component of the endotoxin; the total dose was 3015 $\mu \mathrm{g}$. The immune sera obtained from these animals were heated at $56 \mathrm{C}$ for $30 \mathrm{~min}$ and stored in a refrigerator at - $20 \mathrm{C}$. Agar gel precipitation tests were carried out by the method of Ouchterlony (1953). Different concentrations of antigen and immune sera were placed in the wells appropriately arranged in agar plates. The diameter of the well was $3.8 \mathrm{~mm}$, and the distance between centers of the wells was $15 \mathrm{~mm}$. The precipitation bands were observed after incubation for 1 to 3 weeks at room temperature.

Chemical determinations. Total nitrogen was determined colorimetrically after the wet samples were ashed (Akamatsu, 1952). The amount of phosphorus in the samples was determined by the method of Allen (1940). Reducing sugars were determined by hydrolysis with $1 \mathrm{~N}_{2} \mathrm{H}_{2} \mathrm{SO}_{4}$ in sealed ampoules at $100 \mathrm{C}$ for $6 \mathrm{hr}$, and were evaluated according to the method of Somogyi as modified by Nelson (1944). Pentose and methylpentose were estimated by the method of Dische (Dische and Shettles, 1948; Dische, 1949). Hexosamine and $N$-acetylhexosamine were acetylated with acetylacetone and were determined colorimetrically with Ehrlich's reagent (Elson and Morgan, 1933).

Chromatography. Chromatography was carried out on columns of diethylaminoethyl (DEAE) cellulose, carboxymethyl (CM) cellulose, or Ecteola cellulose (Serva Entwicklungslabor, Heidelberg, Germany). A water suspension of the cellulose powder was allowed to settle for $20 \mathrm{~min}$, and the small particles in the supernatant were removed by decantation. The precipitated celullose was resuspended and packed in a glass tube. About $1 \mathrm{~g}$ of the sample was passed through a column packed with $300 \mathrm{ml}$ of wet cellulose. DEAE and Ecteola cellulose were regenerated with $0.1 \mathrm{~N} \mathrm{NaOH}$, and $\mathrm{CM}$ cellulose was regenerated with $0.1 \mathrm{~N} \mathrm{HCl}$. Each of the columns was washed with water and equilibrated against the starting buffer. Samples were also dialyzed against the same buffer. After passing the sample through the column, samples were eluted by stepwise addition of phosphate buffer and buffered $\mathrm{NaCl}$ solutions of increasing concentrations. The chromatograph was prepared by plotting the results of the colorimetric protein determination by the modified Folin reaction (Lowry et al., 1951), and of sugar obtained from the anthrone reaction (Morris, 1948).

Toxicity test. Different amounts of each sample were administered intraperitoneally to $\mathrm{ddN}$ mice (weighing 15 to $20 \mathrm{~g}$ ), and deaths were recorded 
for 5 days. A group of five mice was used for each amount of test material. The toxicity was expressed by mouse MLD and $\mathrm{LD}_{50}$ (Finney, 1952).

\section{Results}

Chromatography of crude extract. The crude extract resolved into more than four different fractions (A, B, C, D, and others), depending upon the elution schedule applied on the DEAE-cellulose column (Fig. 1). Toxicity tests were carried out on fractions A, B, C, and D (Table 1). It was observed that the toxicity of fractions $\mathrm{A}$ and $\mathrm{C}$ was higher than those of the other fractions.

Purification of fraction A. To 1 volume of fraction A, 0.5 volume of saturated ammonium sulfate solution was added. The precipitate formed was removed, and an additional 0.4 volume of saturated ammonium sulfate was added. The precipitate was dialyzed and rechromatographed on another DEAE-cellulose column. A fraction designated as $\mathrm{AI}$, which was eluted by $0.02 \mathrm{M}$ phosphate buffer ( $\mathrm{pH} 7.5$ ), was concentrated by ammonium sulfate precipitation. This fraction had high toxicity, but the toxicity decreased to onefifth that of the original when heated at $100 \mathrm{C}$ for 10 min (Table 4). Ultracentrifugal studies showed

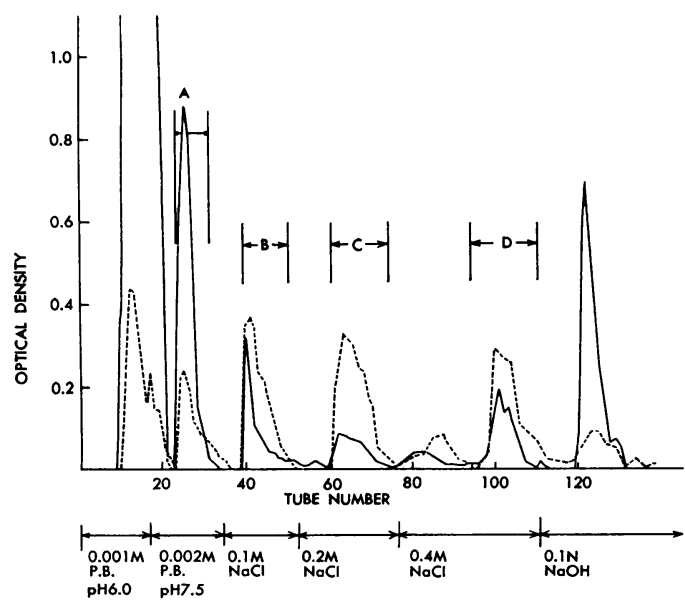

FIG. 1. Chromatography of a crude extract on DEAE-cellulose column. Crude extract (420 mg) was applied to a column (2.8 by $20 \mathrm{~cm}$ ), and 7.5 $m l$ of effluent were collected in each tube. Solid line, optical density at $620 \mathrm{~m}_{\mu}$ in anthrone reaction; dotted line, optical density at $720 \mathrm{m \mu}$ in Folin reaction. Total recovery of protein as measured by Folin reaction was $96 \%$. P.B. = phosphate buffer.
TABLE 1. Toxicity of fractions $A, B, C$, and $D$

\begin{tabular}{c|c|c|c|c|c}
\hline & \multicolumn{5}{|c}{ MLD ( $\mu \mathrm{g})$} \\
\cline { 2 - 6 } Expt no. & $\begin{array}{c}\text { Crude } \\
\text { extract }\end{array}$ & A & B & C & D \\
\hline 1 & 220 & 17.3 & 129 & 56.6 & 280 \\
2 & 162 & 22.3 & 324 & 62.2 & 321 \\
3 & 57.3 & 19.0 & 260 & 64.0 & - \\
4 & - & 12.4 & 32.5 & 58.0 & - \\
\hline
\end{tabular}

TABLE 2. Chemical composition of each fraction

\begin{tabular}{l|c|c|c|c}
\hline \multirow{2}{*}{ Substance } & \multicolumn{3}{|c|}{ Fraction } & Endotoxin \\
\cline { 2 - 5 } & AI & CI & CII & \\
\cline { 2 - 5 } & $\%$ & $\%$ & $\%$ & $\%$ \\
Nitrogen & 8.3 & 15.8 & 14.5 & 1.5 \\
Phosphorus & 1.27 & 2.25 & 1.82 & 0.88 \\
Hexose & 22.4 & 0.68 & 0 & 29.8 \\
Pentose & 0.96 & 0 & 0 & - \\
Methylpentose & 18.9 & 0 & 0 & 22.4 \\
Hexosamine & 6.36 & - & - & 1.21 \\
$N$-acetylhex- & 3.24 & - & - & 0.48 \\
osamine & & & & \\
\hline
\end{tabular}

that this fraction contained more than three components involving a substance of high molecular weight. The results of the chemical analysis indicate that the sugar content is proportional to that of the endotoxin (Table 2). This suggests that fraction A contains a polysaccharide which is one of the components of the endotoxin.

Purification of fraction $C$. Substances of high molecular weight were removed from the crude extract by centrifugation (type $40 \mathrm{P}$, Hitachi Manufacturing Co. Ltd.) at 76,000 $\times g$ for 60 min. Then saturated ammonium sulfate was added to the supernatant. Precipitates formed at $33 \%$ saturation were discarded, and those resulting from addition to $60 \%$ saturation were collected and dialyzed for $6 \mathrm{hr}$ against $0.1 \mathrm{~m} \mathrm{NaCl}$ 0.01 м phosphate buffer ( $\mathrm{pH}$ 7.5). The dialyzed portion was applied to a DEAE-cellulose column, which was equilibrated with the same buffer used for dialysis. The addition of $0.15 \mathrm{~m} \mathrm{NaCl}-0.015 \mathrm{~m}$ phosphate buffer ( $\mathrm{pH}$ 7.5) was followed by a 0.2 м NaCl-0.02 м phosphate buffer of the same $\mathrm{pH}$. The second peak, corresponding to fraction $\mathrm{C}$, was obtained and rechromatographed in a similar 
manner. From $0.5 \mathrm{~g}$ of crude extract, 6.2 to 14.8 $\mathrm{mg}$ of the products were obtained. The collected products, corresponding to fraction $\mathrm{C}$, were allowed to flow through a column of CM cellulose

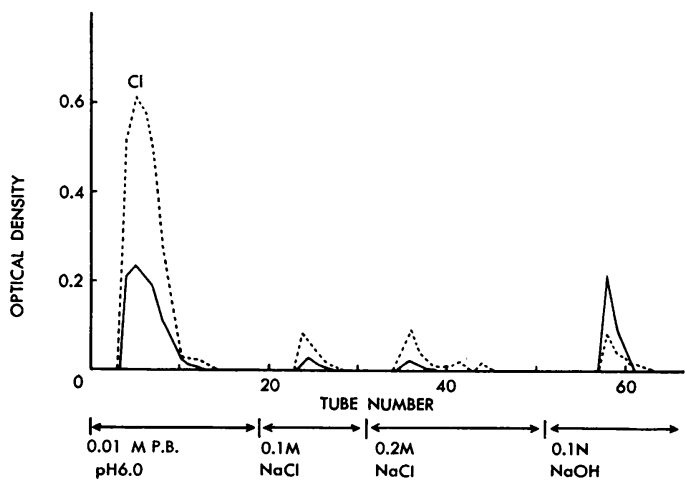

FIG. 2. Chromatography of fraction $C$ on $C M$ cellulose column. Fraction $C(89 \mathrm{mg})$ was applied to a column $(1.2$ by $18 \mathrm{~cm})$, and $7.5 \mathrm{ml}$ of effluent were collected per tube. Solid line, optical density at $620 \mathrm{m \mu}$ in anthrone reaction; dotted line, optical density at $720 \mathrm{m \mu}$ in Folin reaction. The recovery of protein in the first peak was $75 \%$; in total, $96 \%$. P.B. = phosphate buffer.

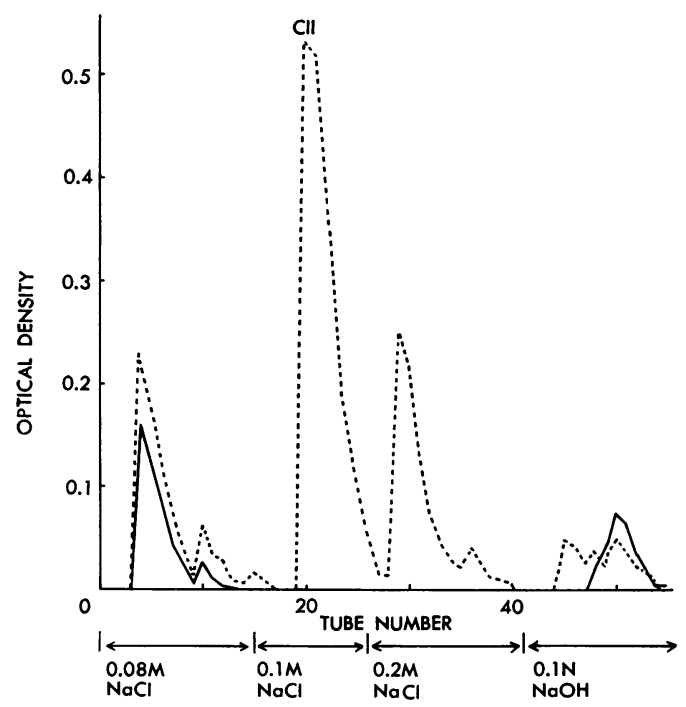

FIG. 3. Chromatography of fraction CI on Ecteola-cellulose column. Fraction CI (51 mg) was charged on a column (1.2 by $13 \mathrm{~cm})$, and $\$ .5 \mathrm{ml}$ of effluent were collected per tube. Solid line, optical density at 620 $\mathrm{m}_{\mu}$ in anthrone reaction; dotted line, optical density at $720 m_{\mu}$ in Folin reaction. Total recovery of protein was $92 \%$ as measured by the Folin reaction.

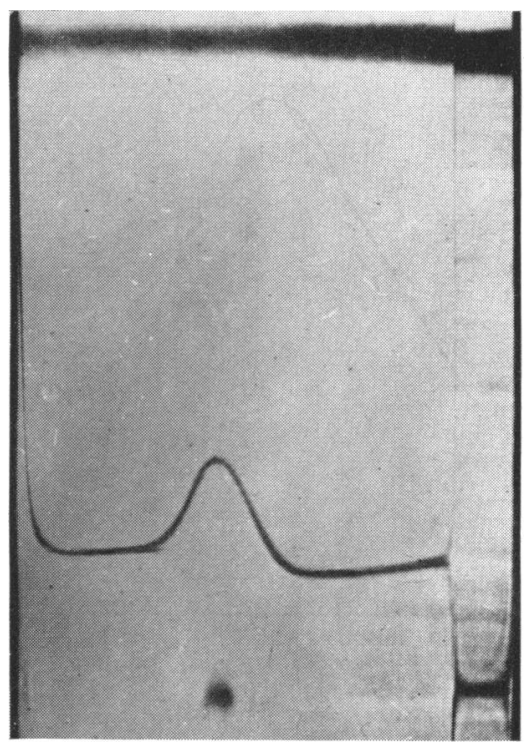

FIG. 4. Sedimentation pattern of CII. Solution of CII (0.82\%) in $0.05 M$ phosphate buffer ( $p H$ 7.5). Rotor speed, 59,000 rev/min; exposure at $75 \mathrm{~min}$.

buffered with 0.01 м phosphate buffer ( $\mathrm{pH} 6.0$ ) followed by elution with the same buffer (Fig. 2). To the effluent of the first peak, saturated ammonium sulfate was added to 52 to $58 \%$ saturation, and a fraction (CI) was obtained. Fractionation of this material was repeated again, and the precipitates were dialyzed against $0.05 \mathrm{M}$ phosphate buffer ( $\mathrm{pH}$ 7.5). The final purification of this fraction (CI) was performed on a column of Ecteola cellulose. The high peak (CII) which resulted from elution with $0.1 \mathrm{M} \mathrm{NaCl}-0.01 \mathrm{M}$ phosphate buffer ( $\mathrm{pH}$ 7.5) contained no sugar detectable by the anthrone reagent (Fig. 3).

Chemical and physical properties of CII. Homogeneity of fraction CII was evidenced by the ultracentrifugal analysis (Fig. 4).

Data shown in Table 2 indicate that CII did not contain any sugar. No peak was found at 380 to $440 \mathrm{~m} \mu$, although $480 \mu \mathrm{g}$ of fraction CII were used for the determination of methylpentose (Fig. 5). A slight rise in the optical density at $570 \mathrm{~m} \mu$ was shown by the anthrone reaction, but no peak was visible at $620 \mathrm{~m} \mu$, which is characteristic for the reaction of hexose (Fig. 6). The CII fraction showed an ultraviolet-absorption spectrum with a maximum at $275 \mathrm{~m} \mu$ (Fig. 7). No reducing sugar 


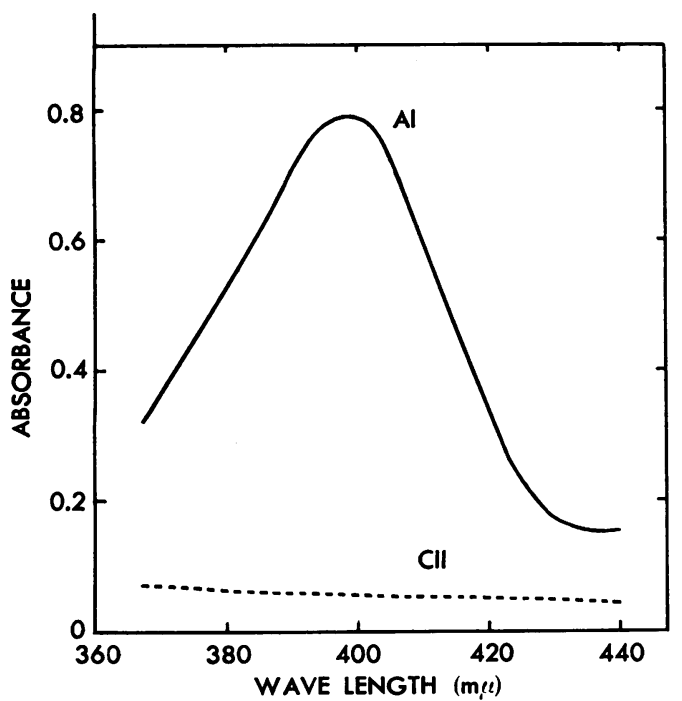

FIG. 5. Absorption spectra of AI and CII. Fractions $A I$ and $C I I$ were dissolved in $0.05 \mathrm{M}$ phosphate buffer ( $p H 7.5)$ at concentrations of 602 $\mu \mathrm{g} / \mathrm{ml}$ and $600 \mu \mathrm{g} / \mathrm{ml}$, respectively. Solid line, AI; dotted line, CII.

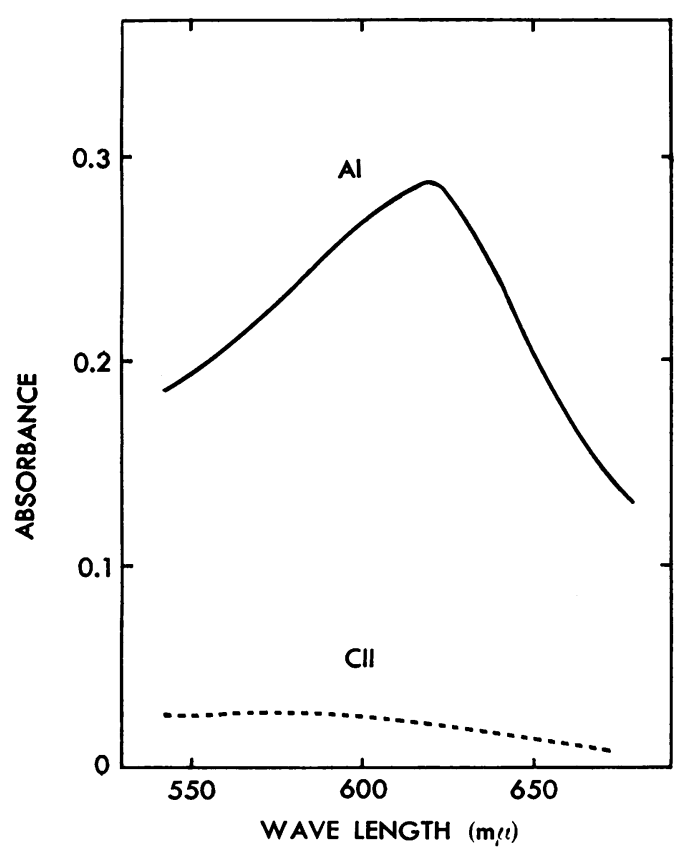

FIG. 6. Color reactions of fractions $A I$ and CII by Dische's method for methylpentose determination. Solid line, $50 \mu \mathrm{g}$ of $\mathrm{Al}$; dotted line, $480 \mu \mathrm{g}$ of $\mathrm{CII}$. was detectable in fraction CII when examined by the Somogyi-Nelson method. The nitrogen content of CII was $14.5 \%$.

From these results, it can be concluded that CII may be a protein which is free from nucleic acid and sugar. The lipid content of CII is now under analysis.

Toxicity of CII. The mouse $\mathrm{LD}_{50}$ of CII was shown to be 24.4 to $26.2 \mu \mathrm{g}$ in different samples prepared by the same procedure. The time necessary for death was $20 \mathrm{hr}$ to 4 days. Dullness and occasional diarrhea, but no neuropathic symptoms, were observed.

No decrease in toxicity of the endotoxin after heating at $100 \mathrm{C}$ for $30 \mathrm{~min}$ was demonstrable

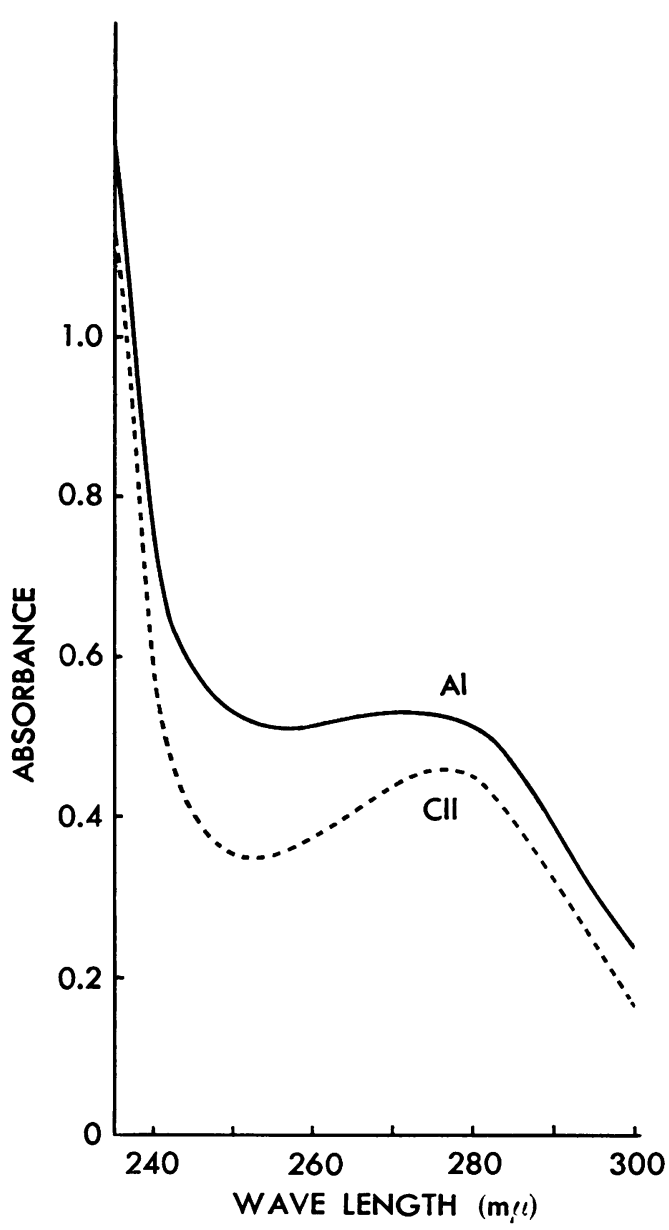

FIG. 7. Color reactions of fractions $A I$ and $C I I$ by anthrone reagent for hexose determination. Solid line, $60 \mu \mathrm{g}$ of $\mathrm{AI}$; dotted line, $120 \mu \mathrm{g}$ of CII. 
TABLE 3. Effect of heating on the toxicity of each fraction

\begin{tabular}{|c|c|c|c|c|}
\hline \multicolumn{2}{|c|}{$\begin{array}{c}\text { Heating (at pH } \\
8.0)\end{array}$} & \multicolumn{3}{|c|}{ LDso ( $\mu g)$} \\
\hline Temp & Time & AI & CII & Endotoxin \\
\hline$C$ & $\min$ & & & \\
\hline $\mathrm{N}^{*}$ & & 10.3 & 26.2 & 185 \\
\hline 100 & 5 & 7.3 & 128.5 & 185 \\
\hline 100 & 10 & 49.9 & 134.2 & 207 \\
\hline 100 & 20 & 49.9 & 245.2 & 162 \\
\hline 100 & 30 & 124.6 & 260 & 222 \\
\hline $\mathrm{N}$ & & 10.3 & 24.4 & 185 \\
\hline 70 & 10 & 18.2 & 52.3 & - \\
\hline 70 & 30 & 16.9 & 107.7 & 198 \\
\hline
\end{tabular}

* Not heated.

TABLE 4. Effect of heating at various $p H$ levels on the toxicity of each fraction*

\begin{tabular}{cccc}
\hline \multirow{2}{*}{$\mathrm{pH}$} & \multicolumn{3}{c}{ LDso $(\mu \mathrm{g})$} \\
\cline { 2 - 4 } & $\mathrm{AI}$ & $\mathrm{CII}$ & Endotoxin \\
\hline $\mathrm{N}$ & 13.5 & 26.1 & 204 \\
4.8 & 28.2 & 124 & 380 \\
6.0 & 57.3 & 178 & 380 \\
7.2 & 32.4 & 152 & 269 \\
8.0 & 121 & 260 & 195 \\
9.0 & - & 260 & 269 \\
\hline
\end{tabular}

* Fractions were heated at $100 \mathrm{C}$ for $20 \mathrm{~min}$ at the $\mathrm{pH}$ indicated. $\mathrm{N}=$ no heating. Buffers used were as follows: $\mathrm{pH} 4.8$ and 6.0 , acetate; $\mathrm{pH} 7.2$ and 8.0, phosphate; $\mathrm{pH} 9.0$, carbonate.
(Table 3). However, the toxicity of both AI and CII decreased markedly upon heating.

The decrease in toxicity of $\mathrm{AI}$ and CII was most obvious upon heating at an alkaline $\mathrm{pH}$, whereas no change in toxicity of the endotoxin was observed under similar conditions (Table 4).

Serological properties of fraction CII. Serological properties of fraction CII and the endotoxin were compared by the Ouchterlony (1953) technique. A sharp band of precipitate was formed between CII and the antibacterial serum, and it crossed over the precipitation band of the endotoxin (Fig. 8a). A single sharp band was observed between CII and the anti-C serum, but no precipitation was formed between the protein component of the endotoxin and this serum (Fig. 8b). The antiserum of a rabbit immunized with the protein component of the endotoxin formed two broad bands and one weak band when tested against the protein component. In this system, the band of CII fused with the weak band of the endotoxin protein (Fig. 8c). From these results, it is believed that the CII fraction is serologically a single substance which differs from the endotoxin, and that it is not the protein portion of the endotoxin, although both possess the same partial antigen.

\section{Discussion}

It has been observed that the water extract of cells from a virulent strain of $S$. enteritidis shows high toxicity, ranging from 31.4 to $220 \mu \mathrm{g}$ in
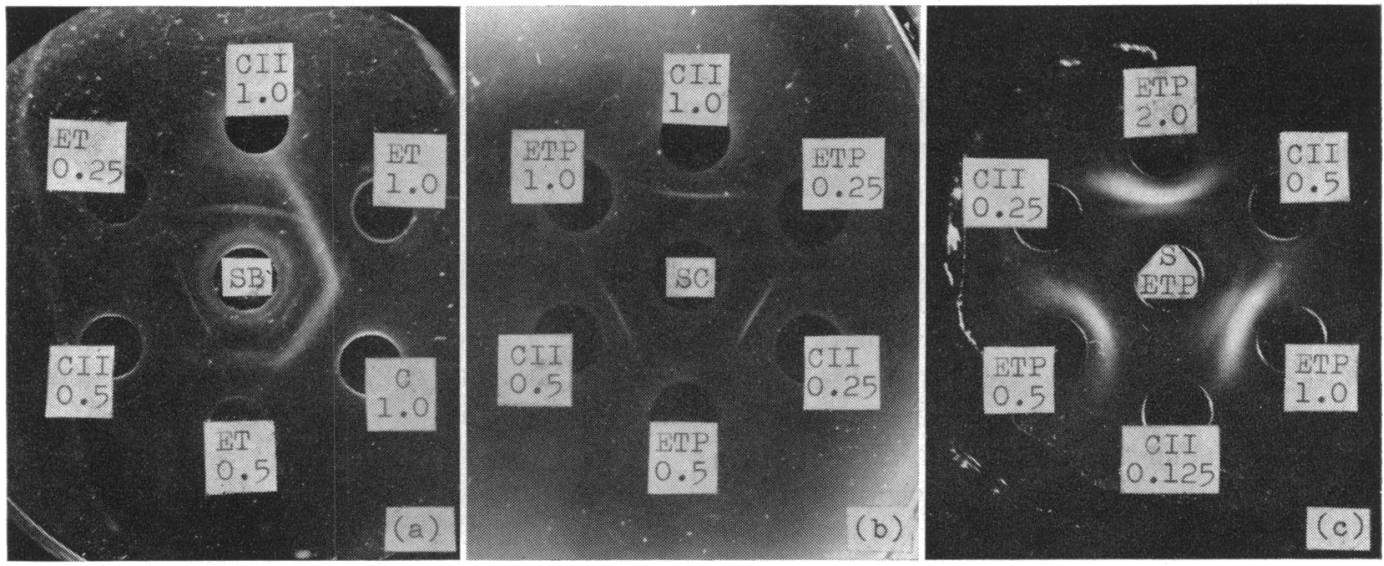

FIG. 8. Precipitation test of toxins in agar gel. $C$ and $C I I$, toxin fractions of $C$ and $C I I ; E T$, endotoxin; $E T P$, protein component of endotoxin; $S B$, antibacterial serum; SC, anti-C serum; SETP, anti-ETP serum. Each number indicates the amount of antigen in $\mathrm{mg}$. (a) Photographed on the 18th day, (b) on the 10th day, and $(c)$ on the 24th day. 
mouse MLD, when it is extracted under low temperature at an alkaline $\mathrm{pH}$. In the present study, this extract was resolved into several fractions by means of cellulose chromatography. One of the fractions, designated as AI, gave a mouse $\mathrm{LD}_{50}$ of 10.3 to $13.5 \mu \mathrm{g}$; its toxicity was 12 times that of the endotoxin obtained from a similar species. The other fraction (C) was purified to a homogenous state by repeated applications of cellulose chromatography. We proposed the term " $L$ " for this purified fraction CII, because CII is labile to heat. The $\mathrm{L}$ is protein in nature and free from polysaccharides and nucleic acids. The mouse $\mathrm{LD}_{50}$ of the $\mathrm{L}$ is $25 \mu \mathrm{g}$. The major differences between these toxins (AI and L) and the endotoxin are their high toxicity and sensitivity to heat. Their toxicity was markedly decreased by heating at $100 \mathrm{C}$ for $20 \mathrm{~min}$. The endotoxin was extracted from $S$. enteritidis by the methods of Boivin and Mesrobeanu (1935), Morgan (1937), Goebel et al. (1945), and Westphal et al. (1952). The LD50 of each extract was, however, 105 to $224 \mu \mathrm{g}$. The toxicity of all these samples was heat-stable (Mitsuhashi et al., 1960).

A toxic component was separated from the endotoxin by Tal and Olitzki (1948) and Tal and Goebel (1950), and was shown to be a conjugated protein or proteinlike component of a lipopolysaccharide-protein complex. On the other hand, some authors (Davies, Morgan, and Record, 1955; Webster et al., 1955; Westphal and Lüderitz, 1954) believed that polysaccharide or lipopolysaccharide is the toxic component of the endotoxin. These components also differ from our toxin in toxicity and heat stability. Serological analysis indicated that the $\mathrm{L}$ is not a protein component of the endotoxin, althought it has a partial antigen of the endotoxin protein.

From a culture medium or the cells of Shigella dysenteriae, a highly toxic substance, neurotoxin, was separated. Neurotoxin has a mouse $\mathbf{L D}_{50}$ of $1.3 \mu \mathrm{g}$, and is heat-labile and proteinlike in nature (Boivin and Mesrobeanu, 1937; van Heyningen and Gladstone, 1953). However, such a neurotoxin has not yet been obtained from $S$. enteritidis. Haas (1940) reported on the absence of an exotoxin of the neurotoxin type in S. enteritidis. The Vi antigen of some enteric bacteria was also separated by many authors (Webster, Landy, and Freeman, 1952). Recently, a heat-labile toxin was found in a culture medium of Escherichia coli (Hohorst, 1953). The toxicity of these toxins, however, is not too high, and no reports on the extraction of such toxins from S. enteritidis are available. Thus, the toxic material separated from $S$. enteritidis is a new type of toxin.

It was observed, furthermore, that toxin $\mathrm{L}$ has an immune effect by protecting mice against infection due to $S$. enteritidis. The role of toxin $L$ during infection by $S$. enteritidis and the immunity against such infection are the necessary problems to be studied. These will be described elsewhere.

\section{Literature Cited}

Akamatsu, S. 1952. Some micromethods for enzyme studies. J. Biochem. (Tokyo) 39:203-210.

Allen, R. J. L. 1940. The estimation of phosphorus. Biochem. J. 34:858-865.

Boivin, A., and L. Mesrobeanu. 1935. Recherches sur les antigènes somatiques et sur les endotoxines des bactéries. I. Considérations générales et exposé des techniques utilisées. Rev. Immunol. 1:553-560.

Boivin, A., and L. Mesrobeanu. 1937. Recherches sur les toxins des bacilles dysentériques. Sur l'existence d'un principe toxique thermolabile et neurotrope dans les corps bactériens du bacille de Shiga. Compt. Rend. Soc. Biol. 126:222-228.

Davies, D. A. L., W. T. J. Morgan, and B. R. RECORD. 1955. Studies in immunochemistry. 15. The specific polysaccharide of the dominant ' $O$ ' somatic antigen of Shigella dysenteriae. Biochem. J. 60:290-303.

Dische, Z. 1949. Spectrophotometric method for the determination of free pentose and pentose in nucleotides. J. Biol. Chem. 181:379-392.

Dische, Z., And L. B. Shettles. 1948. A specific color reaction of methylpentose and a spectrophotometric micromethod for their determination. J. Biol. Chem. 175:595-603.

Elson, L. A., and W. T. J. Morgan. 1933. A colorimetric method for the determination of glucosamine and chondrosamine. Biochem. J. 27:1824-1828.

Finney, D. J. 1952. Probit analysis, a statistical treatment of the sigmoid curve, 2nd ed. Cambridge University Press, Cambridge, England.

Goebel, W. F., F. Binkley, and E. Perlman. 1945. Studies on the flexner group of dysentery bacilli. I. The specific antigen of Shigella paradysenteriae Flexner. J. Exptl. Med. 81: 315-330.

HAAS, R. 1940. Vergleichende Untersuchungen über die toxischen und antigenen Eigenschaften von bei tiefer Temperatur gewonnen löslichen Bakterienbestandteilen der Typhus- 
Paratyphus-Enteritis-und Ruhr-Gruppe. Zugleich 5. Mitteilung der Untersuchungsreihe über Endo und Exotoxine von Dystenteriebazillen. Z. Immunitaetsforsch. 97:317-329.

Hohorst, H. J. 1953. Utber das Ektotoxin von Bacterium coli. Z. Hyg. Infektionskrankh. 136:159-162.

Lowry, O. H., N. J. Rosebrough, A. L. Farr, AND R. J. RANDAll. 1951. Protein measurement with the Folin phenol reagent. J. Biol. Chem. 193:265-275.

Mitsuhashi, S., M. Kawakami, T. Tanaka, and K. Harada. 1960. Studies on the experimental typhoid. VIIa. Endotoxin of S. enteritidis. Japan. J. Bacteriol. 15:84-88.

Mitsuhashi, S., M. Kawakami, Y. Yamaguchi, AND N. Nagar. 1958. Studies on the experimental typhoid. I. A comparative study of living and killed vaccines against the infection of mice with $S$. enteritidis. Japan. J. Exptl. Med. 28:249-258.

Morgan, W. T. J. 1937. Studies in immunochemistry. II. The isolation and properties of specific antigenic substance from Dysenteriae (Shiga). Biochem. J. 31:2003-2021.

Morris, D. L. 1948. Quantitative determination of carbohydrates with Dreywood's anthrone reagent. Science 107:254-255.

Nelson, N. 1944. A photometric adaptation of the Somogyi method for the determination of glucose. J. Biol. Chem. 153:375-380.

Ouchterlony, O. 1953. Antigen-antibody reactions in gel. IV. Types of reactions in coordinated systems of diffusion. Acta Pathol. Microbiol. Scand. 32:231-240.
TAL, C., AND W. F. Goebel. 1950. On the nature of the toxic component of the somatic antigen of Shigella paradysenteriae, Type Z (Flexner). J. Exptl. Med. 92:25-34.

TaL, C., ANd L. Olitzki. 1948. The toxic and antigenic properties of fractions prepared from the complete antigen of Shigella dysenteriae. J. Immunol. 58:337.

Ushiba, D., M. Yoshioka, R. Iwakata, and S. Yamagata. 1953. Studies on the immunity of experimental typhoid. II. Effects of the immunization with killed vaccines on Salmonella enteritidis infection of mice. Keio J. Med. 2:75-90.

van Heyningen, W. F., and G. P. Gladstone. 1953. The neurotoxin of Shigella shigae. 1. Production, purification and properties of the toxin. Brit. J. Exptl. Pathol. 34:202-216.

Webster, M. E., M. Landy, and M. E. Freeman. 1952. Studies on Vi antigen. II. Purification of Vi antigen from Escherichia coli 5396/38. J. Immunol. 69:135-142.

Webster, M. E., J. F. Sagin, M. Landy, And A. G. JoHnson. 1955. Studies on the $O$ antigen of Salmonella typhosa. I. Purification of the antigen. J. Immunol. 74:445-465.

Westrhal, O., ANd O. Lüderitz. 1954. Chemische Erforschung von Lipopolysacchariden gramnegativer Bacterien. Angew. Chem. 66:407417.

Westphal, O., O. Lüderitz, E. EichenberGer, AND W. Keiderling. 1952. Utber bakterielle Reizstoffe. I. Reindarstellung eines Polysaccharide-Pyrogenes aus Bacterium coli. Z. Naturforsch. 7b:536-548. 